\title{
DÉGRADATION « IN VITRO » DE DIFFÉRENTS AMIDONS (MAïs, MANIOC, POMME DE TERRE) PAR LE SUC PANCRÉTIQUE DU PORCELET SEVRÉ A 5 SEMAINES. ÉTUDE MICROSCOPIQUE
}

\author{
Armelle DERRIEN *, D. GALLANT** et A. AUMAITRE *** \\ * Institut de Biologie appliquée à la Nutrition et à l'Alimentation, \\ 21 - Dijon \\ ** Station de Biochimie et Physicochimie des Céréales, C. E. R.D.I.A., \\ 91 - Massy \\ *** Station de Recherches sur l'Élevage des Porcs, C. N.R. Z., I. N. R. A., \\ 78 - Jouy-en-Josas
}

Le porcelet, comme tous les jeunes nourrissons, présente souvent au moment de son sevrage une intolérance à l'amidon que l'on explique par la faible activité de son amylase pancréatique et à la dégradation incomplète des substances amylacées dans son intestin. Nous avons voulu décrire qualitativement les différentes modalités de la digestion de trois amidons d'origine botanique différente (maïs, manioc, pomme de terre), au cours d'un examen microscopique des differentes phases de leur hydrolyse in vitro par les enzymes du suc pancréatique. Dans un second temps, nous avons examiné la dégradation des amidons ayant subi un temps de séjour variable dans l'estomac de l'animal.

\section{Mode opératoire}

Les conditions expérimentales in vitro tiennent compte de la physiologie du porcelet: à une. suspension d'amidon à $4 \mathrm{p}$. Ioo dans le tampon phosphate à $\mathrm{pH}=7$ et $37^{\circ} \mathrm{C}$, on ajoute $300 \mathrm{mg}$ de suc pancréatique lyophilisé (obtenu par fistule pancréatique) + merthiolate de $\mathrm{Na} a ̀$ o,2 p. I ooo. On prélève un échantillon pour examen entre 5 minutes et 24 heures après le début de l'hydrolyse.

Les effluents sont recueillis après administration d'un repas, renfermant $5^{\circ} \mathrm{p}$. Ioo d'amidon sous forme de farine, par fistule permanente du duodénum, au bout de Io $\mathrm{mn}$ et $2 \mathrm{~h}$ de séjour dans l'estomac. A $50 \mathrm{ml}$ de contenu gastrique homogène on ajoute $15 \mathrm{mI}$ de bile fraîche et $150 \mathrm{mg}$ de suc pancréatique lyophilisé. Les prélèvements au cours du temps sont effectués comme pré-. cédemment.

\section{Résultats}

A. - Amidons natifs.

Les observations en microscopie photonique montrent que :

I. L'amidon de maïs est rapidement attaqué par les enzymes du suc pancréatique (formation: très visible de pores avant les 5 premières minutes; entre 5 et $\mathrm{r}_{5} \mathrm{mn}$ tous les grains d'amidon. sont partiellement attaqués. La dégradation provoque des pores puis des canaux profonds, et. enfin une "digestion " du centre des grains (environ I heure après le début de l'hydrolyse).

2. L'amidon de manioc semble plus résistant à l'attaque. Mais la dégradation affecte d'abord une zone sensible, la partie tronquée de ce grain hémisphérique, puis gagne le centre des grains. (4 à 5 heures). 
3. Par contre, l'amidon de pomme de terre apparaît très résistant et la dégradation se présente sous forme de sillons superficiels ( 16 à. 20 heures).

Les observations en microscopie électronique à transmission, après fixation, coloration et coupes ultrafines des échantillons, confirment les résultats précédents, montrant surtout l'attaque centrale des grains d'amidons de maïs, après introduction de l'amylase par de nombreux pores.

La microscopie électronique à balayage (scanning) nous permet de bien mettre en évidence, sur échantillons entiers ayant subi une simple métallisation, la morphologie de la dégradation des amidons selon leur origine botanique. Le maïs se dégrade en profondeur après formation de pores qui se creusent et découpent de très larges cavernes dans les grains dont les couches superposées s'individualisent par un processus de corrosion différentielle. L'amidon de pomme de terre ne se dégrade pas en profondeur : des " pores " apparaissent en surface des grains et s'élargissent en sillons mais l'érosion demeure superficielle (fig. I $a, b$ ). Ces différents résultats sont à rapprocher des hypothèses formulées par BAKER (1950) relatives aux modalités de la dégradation bactérienne de l'amidon suivant son origine.

\section{B. - Contenus gastriques.}

Une comparaison avec les résultats obtenus in vitro sur les amidons natifs montre l'influence non négligeable que constitue la phase gastrique, l'hydrolyse de l'amidon semblant proportionnelle au temps de séjour dans l'estomac. Dans ces conditions, on observe une nette accélération du processus de dégradation en ce qui concerne l'amidon de mais et de manioc. Le cas de l'amidon de pomme de terre est plus particulier en ce sens que l'hydrolyse est plus complète que précédemment, et la dégradation atteint les parties profondes des grains.

\section{Conclusions}

Les observations effectuées en microscopie recoupent les résultats relatifs à la vitesse d'hydrolyse de l'amidon mesurée par l'intensité de l'absorption du glucose dans la veine porte après le repas, chez le porcelet. Ils permettent de conclure à :

I. La digestion rapide de l'amidon de mais, se traduisant par une augmentation de la glycémie dans les toutes premières minutes consécutives à l'ingestion de la ration ;

2. La digestion plus lente de l'amidon de manioc : augmentation plus lente de la glycémie.

3. La digestion très faible de l'amidon de pomme de terre : pas d'augmentation notable de la glycémie dans les heures suivant le repas.

\section{Orientation des travaux}

Le rôle non négligeable de certains facteurs digestifs situés en amont de la digestion intestinale (rôle de la salive, du suc gastrique, des variations de $\mathrm{pH}$, des interactions entre les composants, etc.) ainsi que l'importance déterminante des traitements technologiques de l'aliment, nous conduisent à porter en priorité nos efforts :

I. Sur l'étude des principales étapes de la digestion de l'amidon au cours du transit digestif, les essais effectués in vitro ayant pour objet d'isoler les différents facteurs et de pouvoir chiffrer leur action ;

2. Sur l'influence de traitements technologiques élémentaires subis par le grain d'amidon pendant la granulation. 

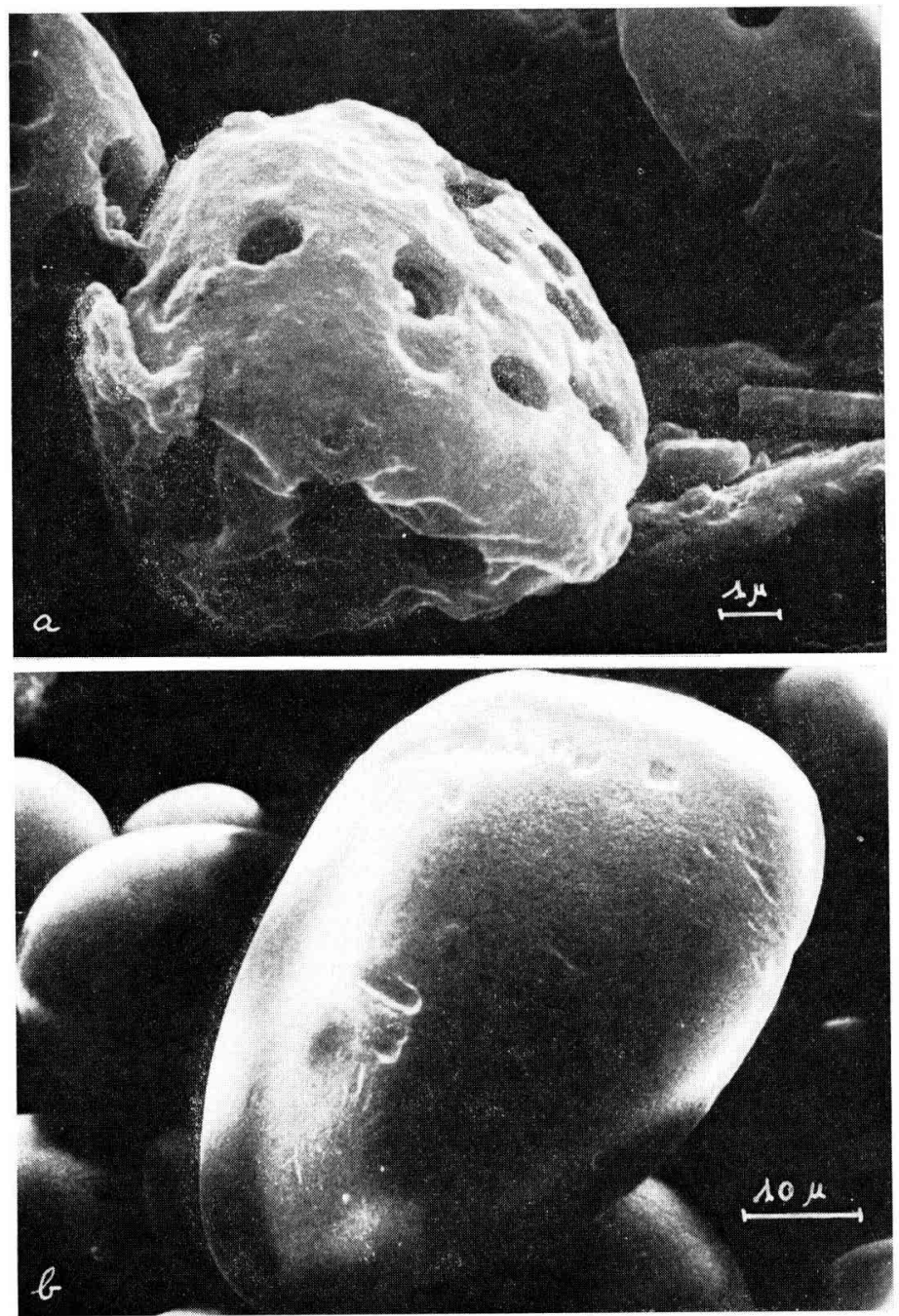

FIG. I. - Hydrolyse de l'amidon, in vitro, pendant 24 heures, par le suc pancréatique du porcelet sevré à 5 semaines

a) Amidon de Maïs : la dégradation du grain d'amidon commence par l'apparition de pores qui se creusent ensuite en de larges cavernes. La dégradation s'effectue en profondeur.

b) Amidon de Pomme de terre : des dépressions circulaires apparaissent à la surface du grain et s'élargissent en sillon. La dégradation demeure superficielle.

Ces photographies ont été réalisées à l'aide du microscope à balayage JSM-U(3) et grâce à l'amabilité de la Société Jeolco que nous remercions bien vivement.

FIG. I. - In vitro hydrolysis of starch after 24 hours

by the pancreatic juice of a piglet weaned at 5 weeks

a) Maize starch : breakdown of the starch grain begins with the appearance of pores which later develop in to large hollows. There is breakdown inside the grain.

b) Potato starch : circular depressions appear on the surface of the grain and enlarge into furrows. Breakdown remains superficial.

We wish to acknowledge the kindness of the "Societé Jeolco " (Rueil-Malmaison) for the use of the scanning microscope JSM-U 3 for these photographs. 


\title{
SUMMARY
}

\author{
IN VITRO BREAKDOWN OF VARIOUS STARCHES \\ (MAIZE, MANIOC AND POTATO) BY THE PANCREATIC JUICE \\ OF THE PIGLET WEANED AT 5 WEEKS. MICROSCOPICAL, STUDIES
}

The suckling piglet shows an intolerence to starch at the time of weaning that is explained by the low activity of its pancreatic amylase and the incomplete breakdown of starch substances in the intestine. In the first instance, the different modes of digestion of starches from different botanical origins (maize, manioc and potato) have been described qualitatively during a microscopical examination of the different phases of their in vitro hydrolysis by the enzymes of the pancreatic juice. Secondly, we have examined the breakdown of starches that have remained for various lengths of time in the animal's stomach.

\section{Experimental methods}

The In vitro experimental conditions take into account the physiology of the piglet : $300 \mathrm{mg}$ of lyophilized pancreatic juice (obtained by means of a pancreatic fistula) and 0.02 p. Ioo sodium merthiolate are added to a suspension of $4 \mathrm{p}$. Ioo starch in phosphate buffer at $\mathrm{pH} 7.0$ and $37^{\circ} \mathrm{C}$. A sample is taken for examination between 5 minutes and 24 hours after the beginning of hydrolysis.

The effluents are collected after feeding a meal containing $5^{\circ} \mathrm{p}$. Ioo starch, by means of a permanent duodenum fistula, after the food has been in the stomach for $10 \mathrm{mn}$ and $2 \mathrm{~h}$. Fifteen $\mathrm{ml}$ of fresh bile and $5^{\circ} \mathrm{mg}$ of lyophilized pancreatic juice are added to $50 \mathrm{ml}$ of homogenous gastric contents.

\section{Results}

\section{A. - Native starches.}

Observations by means of microphotographs have shown that :

I. Maize starch is rapidly attacked by the enzymes of the pancreatic juice (clearly visible formation of pores before the first 5 minutes). All starch grains are partially attacked between 5 and 15 minutes. Breakdown begins with the formation of pores, followed by deep channels, and then a final "digestion" of the center of the grain (about I hour after the begin ning of hydrolysis).

2. Manioc starch appears to be more resistant to attack. A sensitive zone, the truncated part of this hemispherical grain, is first affected ; then the center of the grain is attained ( 4 to 5 hours).

3. Potato starch appears, on the other hand, to be very resistant and there is only slight breakdown along superficial furrows (I 6 to 20 hours).

Electron microscope observations of ultrathin sections of the samples, prepared after fixation and staining, confirm the former results, and particularly the Central attack of the maize starch grain through its center after amylase has penetrated through numerous pores.

Scanning microscope observations of whole samples subjected to a simple metal treatment have demonstrated the morphology of the breakdown of starches following their botanical origin. Maize is broken down inside the grains after the formation of pores which become separated by a process of differential corrosion. Granules of potato starch are not brokendown inside, pores appear on the surface, followed by furrows, but erosion remains superficial.

These various results may be aligned with the hypotheses formed by BAKER (1950) with regard to the mode of bacterial degradation of starch with relation to its origin.

Annales de Biologie animale. - I97r. 


\title{
B. - Gastric contents.
}

When the in vitro results on the native starches are compared with the results of in vivo experiments, it may be seen that the gastric phase has an important influence - the hydrolysis of starch seems to be proportional to the time of remaining in the stomach. There is a definite acceleration of the breakdown process of maize and manioc starch under theses conditions. In comparison with the in vitro results, potato starch breakdown differs in that the deep areas of the grains are attained and hydrolysis is more complete.

\section{Conclusions}

It may be concluded from microscopical observations combined with the results obtained in vivo on the rate of starch hydrolysis, as measured by glucose absorption into the portal vein after feeding, that :

I. The rapid digestion of maize starch is shown by an increase in glycaemia during the very first minutes after feeding.

2. The slower digestion of manioc starch is accompanied by a slower increase in glycaemia.

3. The very low digestion of potato starch is shown by the fact that there is not much increase in glycaemia during the hours following feeding.

\section{Plan of research}

Since certain factors play quite an important role in digestion before intestinal digestion takes place (saliva, pancreatic juice, variations in $\mathrm{pH}$, interactions between components, etc.) and since technological treatment of the feed has a great importance, future work will be directed primarily towards :

r. A study of the principal stages in the digestion of starch during transit through the digestive tract. The object of experiments carried out in vitro will be to separate the different factors and to define their action.

2. A study of the influence of elementary technological treatments of the starch grain during pelleting of the feed.

\section{Évolution de L'ACtivité lactasiQue de L'intestin du PORC EN FONCTION DU RÉGIME}

\author{
C. FÉVRIER et A. AUMAITRE
}

Station de Recherches sur l'Élevage des Porcs, Centre national de Recherches zootechniques, I. N. R. A., 78 - Jouy-en-Josas

L'utilisation de grandes quantités de lactosérum, donc de lactose par le Porc en finition suppose une possibilité d'hydrolyse de ce glucide et éventuellement une adaptation à ce type de régime.

A l'issue d'une expérience au cours de laquelle les porcs ont reçu o, ro et $20 \mathrm{p}$. Ioo de sérum sec entre 5 semaines et le poids de $30 \mathrm{~kg}$, puis o, 30 et $60 \mathrm{p}$. 1oo de sérum jusqu'à $90 \mathrm{~kg}$, on a déterminé l'activité enzymatique du pancréas et du duodénum vis-à-vis du lactose. En outre, sur 